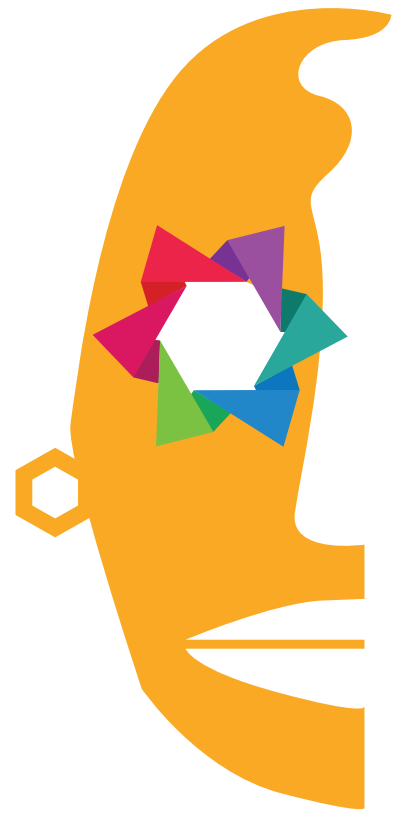

Nelson René

Carrasco Casco

Universidad Nacional

Autónoma de Honduras

Honduras

Josué Omar

Flores Osorto

Universidad Nacional

Autónoma de Honduras

Honduras

\section{Arte, culto y devoción: la imagen de San José en la cultura hondureña}

\section{Resumen}

La presente investigación pretende hacer un análisis histórico sobre la figura de San José y sus diferentes manifestaciones en la cultura y sociedad hondureña, como consecuencia de su culto, creación artística y devoción popular. Este culto tiene su origen en la época colonial, específicamente en el s. XVI, con los Concilios de Trento (1545 - 1563), Nueva España $(1555,1565,1585)$ y Lima, Perú (1556 y 1561), los cuales contribuyeron a expandir el evangelio desde la iconografía hasta la fundación de poblados que adoptaron esta imagen como Santo Patrón. También, se analiza esta imagen en el imaginario hondureño durante la secularización del Estado, su adopción y creación como un ideal de paternidad que simboliza protección, sustento y responsabilidad en la construcción de la organización familiar, finalizando con la vinculación de San José como patrono de la clase obrera en el siglo XX.

Palabras clave: Arte, culto, devoción, San José, fiestas patronales, religiosidad popular, Honduras.
Abstract
The present investigation intends to make a historical analysis about the figure of San José and its different manifestations in Honduran culture and society, as a consequence of its cult, artistic creation and popular devotion. This cult has its origin in the colonial era, specifica- lly in the sixteenth century, with the Councils of Trento (1545 - 1563), New Spain $(1555,1565,1585)$ and Lima, Peru (1556 and 1561), which contributed to expand the gospel from iconography to the founding of villages that adopted this image as Patron Saint. Also, this image is analyzed in the Honduran imaginary during the secularization of the State, its adoption and creation as an ideal of paternity that symbolizes protection, sustenance and responsibility, in the construction of the 
family organization, ending with the connection of San José as patron of the working class in the twentieth century.

Keywords: Art, worship, devotion, San José, patron festivals, popular religiosity, Honduras.

\section{Introducción}

El estudio de las devociones cristianas ha constituido un verdadero hito en la historiografía hondureña, ya que siempre se le dado mayor interés a temáticas de orden político, dejando de lado las manifestaciones culturales y religiosas que por siglos se han practicado en el territorio, como son las fiestas patronales y las devociones populares. En este sentido, son pioneras las obras de Leticia de Oyuela: Honduras: Religiosidad popular. Raiz de la identidad (1995) y De santos y pecadores: un aporte para la historia de las mentalidades (1546-1910) (1999), las cuales nos acercan al estudio de la cultura y religiosidad popular manifestada en el imaginario hondureño.

Según Oyuela, en América Latina, los santos juegan un papel fundamental en la lucha contra el demonio y las representaciones del mal: enfermedades, terremotos, lluvias y pestes, siendo estos la oposición para cada una de estas adversidades, por ejemplo:

San Roque, contra las pestes, San Ramón Nonato, para los partos, San Rafael, para los distintos tipos de enfermedades; San José; padre universal, consigue marido, cuidador y delicado; San Antonio, consigue novio y encuentra los objetos perdidos, hasta para la tos estaba San Blas, con su invocación San Blas, San Blas, que no se atore más. (Oyuela, 1995, p. 196)

Al reconocer el papel fundamental de cada santo en el sentido que le otorgan muchas personas, se cree pertinente desarrollar la presente investigación, la cual gira en torno a la conceptualización y ejemplificación de San José como santo representativo de la cristiandad, para ello se abordará su figura desde el punto de vista teológico, iconográfico y popular, examinando esculturas, fiestas patronales e invocaciones en rezos y novenas.

Para comprender el significado de la imagen de San José, se utiliza el método iconográfico según Panofsky (1987) aplicado a las artes visuales (pintura, escultura, arquitectura, fotografías, grabados, impresos), desde tres niveles: Descripción Pre-Iconográfica, Análisis Iconográfico e Interpretación Iconológica.

Un aporte importante para este método lo realiza Burke con su obra, Visto y no visto. El uso de la imagen como documento histórico (2001). En esta obra, Burke (2001), realiza una historia cultural de la imagen, donde vincula la interpretación 
de la iconografía e iconología con el análisis de las imágenes religiosas, indicando que las imágenes pueden considerarse sagradas y sobrenaturales, ya que "desempeñan un papel primordial a la hora de producir la experiencia de lo sagrado" (p. 59).

Para el análisis de las fiestas populares en honor a San José, se emplea la etnografía, la cual es comprendida aquí como el estudio personal en las comunidades, cuyo objetivo principal es registrar, conocer, describir y explicar la realidad sociocultural de una comunidad o de un aspecto en específico del lugar donde se realizará el trabajo de campo, donde se aplican encuestas, observación participante y entrevistas dirigidas.

Finalmente, se utiliza el análisis de contenido, basándonos para ello en la lectura documental como instrumento de recolección sistemática de la información objetiva, replicable y válida; tanto de los periódicos como de las revistas consultadas en la Hemeroteca del Archivo Nacional de Honduras.

\section{Arte, culto y devoción en la América colonial}

Arte, culto y devoción son manifestaciones que nos han legado un rico patrimonio, tanto material como inmaterial. Objetos religiosos provenientes del ámbito privado y público son portadores de una creencia y un vínculo a lo sobrenatural presente en la humanidad desde el principio de los tiempos (Martínez, 2011).

A partir del siglo XVI, se instaló en América un complejo imaginario que buscó el dominio hispánico de este territorio, convirtiéndose en uno de los instrumentos de evangelización por parte de la Iglesia católica. En este sentido, la Iglesia utilizó las imágenes para dos fines principales: reverenciar a los santos, y mover la voluntad del pueblo y despertar la devoción por ellas (Plazaola, 1996).

En el inicio de la época moderna, como respuesta a la reforma protestante, el Papa Paulo III -a instancias del emperador Carlos V- convocó en 1545 a un Concilio en la ciudad italiana de Trento, el cual se extendió hasta 1563. Durante el Concilio el Papa ordenó a todos los obispos y las personas que tienen el cargo y obligación de enseñar, a que instruyeran con exactitud a los fieles sobre la intercesión e invocación de los santos, el honor de las reliquias, y el uso legítimo de las imágenes, según las costumbres de la Iglesia católica y apostólica. A este Concilio se le conoció como La Contrarreforma.

Enseñándoles que los santos reinan juntamente con Cristo, ruegan a Dios por los hombres; que es bueno y útil invocarlos humildemente y recurrir a sus oraciones, intercesión, y auxilio para alcanzar de Dios los beneficios por Jesucristo su hijo y que piensan impíamente los que niegan que se debe invocar los santos 
que gozan en el cielo de eterna felicidad; o los que afirman que los santos no ruegan por los hombres. (Borrero, 1983, p. 742)

Además de esto, se declaró que se debían tener y conservar, principalmente en los templos, las imágenes de Cristo, de la Virgen Madre de Dios y de otros santos, donde se les brindara el honor correspondiente y la respectiva veneración.

En este sentido, Mâle (1996) citado por Martínez (2011) afirma que "conocer la vida de los santos equivalía a conocer la humanidad y la vida entera; en ellas se podía estudiar cada edad y todas las condiciones humanas. La imagen de culto contiene algo incondicionado" (p. 15). Los santos significaban más que devoción: histórica y culturalmente son una representación del sujeto ideal para una sociedad.

En el Primer Concilio Mexicano, celebrado en 1555, se favoreció el culto a los santos: los "patrones de las iglesias catedrales y de los pueblos". Ahí, se designó a San José como patrono de la Iglesia mexicana en sus condiciones de intercesor tradicional contra "las tempestades, el trueno, los rayos y el granizo que tanto atormentan esta comarca" (Gruzinski, 1994, p. 110).

Para evangelizar a "los indios", algunos religiosos crearon catecismos que representaban visualmente los rudimentos de la doctrina cristiana en tiras dibujadas. Esto llevó a que los santos se volvieran símbolos del pueblo, de la comunidad en torno a la cual los campesinos e indígenas reconstruyeron nexos sociales y culturales, al abrigo de las intrusiones de los españoles en el siglo XVII.

En este sentido, imagen y santo quedaron asociados por doquier. No es posible explorar la primera sin tener en cuenta a la segunda. Se crearon, además, instituciones para orientar a los fieles en el culto y reproducción de la imagen del santo, convirtiéndose así en "una persona" con la cual su poseedor y los cofrades establecieron relaciones familiares, al devenir una entidad que podía recibir padrinos o madrinas en el seno del grupo doméstico o de la comunidad.

Así pues, algunos indios deseaban ser enterrados cerca del santo al que más veneraban. Esta proximidad física, el cuerpo del difunto asociado para siempre a la imagen, contribuyó a personalizar las relaciones y a manifestar en el imaginario una serie de lazos que la familia cristiana, restringida y monógama, supuestamente encarnaba y materializaba en la tierra. (Gruzinski, 1994, p. 190)

\section{La figura de San José desde la representación teológica}

"Uno de los santos más gloriosos del catolicismo fue San José, a quien el Señor le concedió la extraordinaria gracia de darle por esposa a la Santísima Virgen y ser padre nutricio del Verbo encarnado" (Luna, 2001, p. 7). No obstante, el culto fue 
tomado en consideración tardíamente por parte de los eclesiásticos, siendo su conmemoración el 19 de marzo, fecha promulgada en 1621 por el papa Gregorio XV.

La propagación de la devoción a San José se desarrolló en el siglo XVII. Dicha devoción fue fomentada principalmente por las dos ramas carmelitas, junto a otras congregaciones religiosas como jesuitas, franciscanos, capuchinos, teatinos, cistercienses, tanto en Europa como en América (Laurentino, 1982).

En esta difusión influyó la devoción popular, con sus propias manifestaciones: las prácticas piadosas y la fundación de muchas cofradías, con su doble vertiente de difusión del culto y beneficencia entre los cofrades y hacia el resto. Aparte de la devoción popular, se robusteció este culto por una predicación encomiástica de notable base teológica y la formación de una literatura sobre temas josefinos sólidamente fundamentada (Laurentino, 1982).

Para el teólogo P. José Antonio Carrasco, presidente de la Sociedad Iberoamericana de Josefología,

San José es un verdadero padre en una doble vertiente padre de Jesús y padre espiritual de la Iglesia, y, por tanto, de todos los cristianos. La paternidad de San José es virginal, por su matrimonio virginal con María, adoptiva, en cuanto Jesús le adopta como padre, para que José lo sea realmente y con todas las consecuencias, y legal. (Laurentino, 1982, p. 357)

\section{Representaciones iconográficas de San José}

Para comprender el desarrollo de la iconografía de San José es necesario conocer cómo el cristianismo condujo al culto del santo. José, descendiente del rey David, figuró como padre nutricio de Jesús, esposo de María y cooperador en el misterio de la encarnación, misión que la Iglesia no consideró importante en un principio. Fue a finales de la Edad Media cuando los teólogos ensalzaron la dignidad y santidad del personaje como modelo de esposo, padre y trabajador.

Los padres de la época primitiva prácticamente ignoraron la figura de San José por dedicarse a divulgar el mensaje de Cristo y cuando lo mencionaban, era sólo por algún hecho relacionado con el misterio cristológico. Los padres griegos, en especial San Juan Crisóstomo, desarrollaron el tema josefino en el siglo IV d.C., al igual que los padres latinos como San Jerónimo y San Agustín. Este último hizo un estudio sobre la santidad, genealogía, matrimonio y paternidad de José (Luna, 2010). Hasta en los siglos XII y XIII hay un gran silencio sobre el tema que vuelve a aparecer con los escritores y reformadores eclesiásticos.

San José, quien practicó las virtudes de la pobreza, la castidad y la obediencia, fue tomado como modelo ejemplar por las órdenes monásticas. Es importante 
resaltar que muchos aspectos de la vida de San José son oscuros, pues es poco lo que relatan los evangelios de Lucas y Mateo, únicas fuentes principales de la vida del santo. De ahí que los artistas tomaron de los evangelios apócrifos y la Leyenda dorada muchos datos ocultos de San José (Luna, 2001).

\section{San José y sus atributos}

En las pinturas antiguas aparece San José como un hombre viejo con barba larga, porque en los primeros tiempos de la época cristiana era necesario afianzar la doctrina de la virginidad de María, de modo que los artistas debían representar a un José anciano en el momento del nacimiento del niño, demostrando la madurez de un padre adoptivo.

Por la influencia de Santa Teresa de Jesús, el culto se difundió durante el siglo XVI, al igual que las imágenes de San José. Desde ese momento hasta el siglo XVIII se generó polémica acerca de qué manera se debía representar al santo. Luna (2001) indica que:

El teólogo Canisius apoyaba a los artistas que seguían la tradición de representar a San José como un anciano, pues los fieles ya estaban acostumbrados a esa imagen. En contraposición, Molanus abogaba por que los artistas consideraran al santo como un hombre joven y vigoroso que sirvió de protector a la Virgen, lo cual fue apoyado por muchos escritores de la época. (p. 14)

De modo que desde el siglo XVI aparece San José con cabellos negros sin la calvicie tradicional, joven y bello; no obstante, persistió el modelo antiguo de representarlo como un anciano, sobre todo en Italia. Además, aparecen algunas imágenes del santo completamente a solas, portando un báculo florecido, atributo tomado de los evangelios apócrifos como signo de su virginidad. De acuerdo a Luna (2001) que sigue a Revilla (1995), "a partir del siglo XVI comenzó a ser representado como un varón maduro en su plenitud. Cuando no empuña la vara, sus atributos son algunas herramientas de carpintero. Muy a menudo, sostiene en brazos al niño Jesús" (p. 15).

San José es representado desde entonces como un hombre joven que lleva de la mano a Jesús con una vara florida. Esta se considera la imagen prototípica que se encuentra en España y América, y que tiene como modelo los grabados flamencos.

El país que probablemente aceptó más los cambios del tipo de representación fue España. San José tomó un lugar importante en la producción pictórica de Murillo, quien sacó de la sombra al personaje para resaltar sus valores como trabajador y padre de Jesús, representándolo con vigor y nobleza, solo o en el grupo de la Sagrada Familia. Otros pintores que lo reprodujeron fueron Zurbarán y El Greco, en obras como San José y el niño Jesús (1597 - 1599). 
Lógicamente la efigie de San José fue más representada con la Sagrada Familia que de forma individual. Conforme a esto, hay imágenes donde el santo es la figura central y en otra forma parte de un episodio con un rol secundario, de manera que se puede hablar de imágenes devocionales e imágenes narrativas. Dentro de las primeras se tienen: San José y el Niño (1597 - 1599), Los Sueños de San José (1620), La Coronación y Muerte de San José (finales del siglo XVII). Entre las imágenes narrativas están: Los Desposorios de la Virgen (1504), La Visitación (1517), La Natividad (1470 - 1485), La Adoración de los Magos o Epifanía (1485 - 1500), La Huida a Egipto (1303 - 1306), La Presentación de Jesús en el Templo (1670) y La Circuncisión (1490 - 1491) (Luna, 2001).

\section{Iconografía de San José en los templos coloniales de Honduras}

Sin duda alguna, la imagen de San José se ha perpetuado en el imaginario y la memoria colectiva desde la época colonial, el padre terrenal de Jesús aparece representado en la mayoría de los templos como patrono universal, como el santo más conocido después de la Virgen María. Su máximo esplendor en la imaginería colonial se desarrolla en el siglo XVIII, principalmente en la sede del Obispado de Comayagua y la Alcaldía Mayor de Tegucigalpa.

Iniciaremos con la iconografía representada en la Catedral de Comayagua, donde la fachada fue concebida como una exaltación a la Concepción de María que señorea en el tercer cuerpo de la calle central acompañada de San José y San Juan Evangelista, ambos testigos de la Concepción Inmaculada de María, San José lleva de la mano al Niño Jesús, mientras que San Juan lleva de la mano el testimonio escrito que dejo el Nuevo Testamento (Martínez, 1997).

En el interior de la Catedral de Comayagua se destacan importantes obras de arte, producto de la expansión universal del discurso de la Iglesia, en este caso obedeciendo al recién creado Arzobispado de Guatemala (1743) de donde provienen la mayoría de los artistas de la época.

Al museo religioso de la ciudad se trasladaron obras pintadas por Blas de Mesa en el año 1724 y, sobre todo, el San José del pintor indígena hondureño José Miguel Gómez, firmado y fechado en 1778, pintura destacada por el oro que invade los lienzos cubiertos de pequeñas flores doradas, los mantos, las vestiduras, los nimbos y los resplandores (Martínez, 1997).

Una característica especial -que denota una escuela local- es la de las pinturas de San José que se encuentran en la catedral, el museo y en algunas casas particulares, donde tanto San José como el Niño Jesús tienen en sus cabezas grandes coronas imperiales. Probablemente esta particularidad sea la solución a una bula papal llegada a Comayagua en 1775, donde se declaraba a San José Patriarca de América. 
Figura 1. San José con el niño Autor José Miguel Gómez (1778)

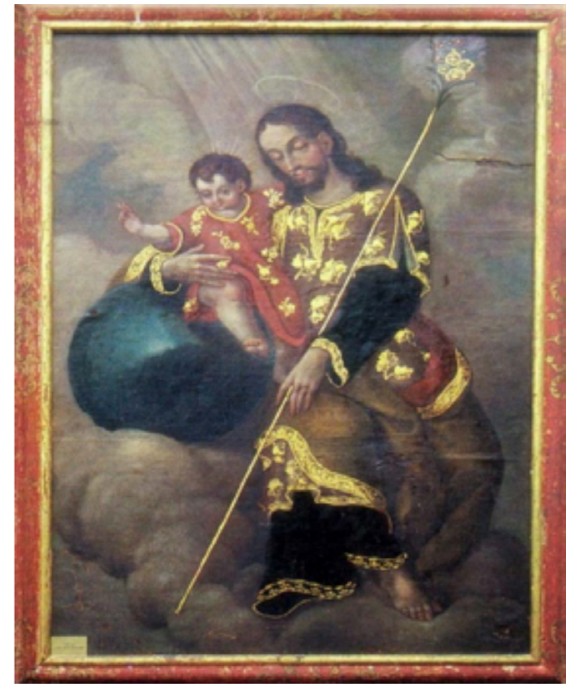

Figura 2. San José y el niño Jesús coronado como Patriarca.

Museo de arte colonial Comayagua

Siglo XVIII

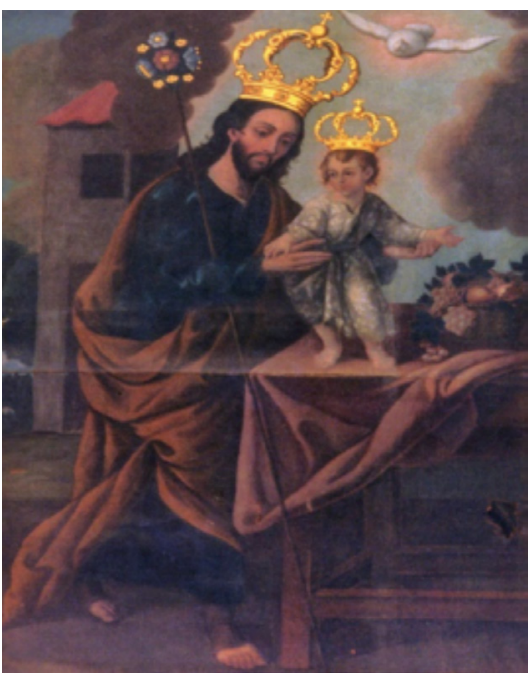

Fuente: Grupo Financiero El Ahorro Hondureño, 2000, pp. 78 y 79.

En cuanto a la lectura del mensaje iconográfico e iconológico de la actual Catedral de Tegucigalpa, debe de tomarse en cuenta el desarrollo de estas devociones paralelas a su construcción, como un proceso de actualización de la Iglesia católica expresada en la fundación del Arzobispado de Santiago de Guatemala.

En el exterior de la Catedral de Tegucigalpa hay dos pórticos, ambos cuentan con dos hornacinas con esculturas. La del lado del Evangelio, posee en la parte inferior a un ángel y en la superior a San José. La relación de ambas esculturas alude al papel de los ángeles como mensajeros divinos. San José porta al Niño Jesús, evidencia que nos permite establecer como lectura didáctica aplicada: "El sueño de San José, cuando un ángel le anunció el nacimiento de Jesús por intervención del Espíritu Santo" (Mateo 1: 20-21), y cuando otro ángel "le avisa para salvaguardar al Niño Jesús de Herodes y huyen a Egipto" (Mateo 2:13) (Urquizú \& Carrasco, 2016, p. 24).

En el interior, tanto en el retablo mayor como en el púlpito, se encuentran las obras del escultor guatemalteco Vicente Gálvez, quien llegó a Tegucigalpa llamado por el bachiller José Simón de Zelaya, para la hechura de los altares de la Parroquia de San Miguel. Los dos retablos laterales, tanto el de las Ánimas como 
Figura 4. San José como protector del niño Jesús, Catedral de Tegucigalpa. Tegucigalpa.

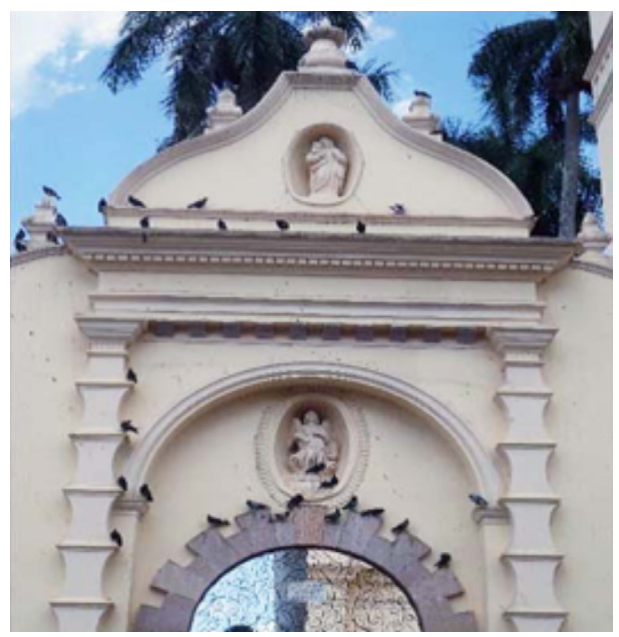

Fuente: Fotografía de Nelson Carrasco, 2016.
Figura 5. San José cargando el niño con bastón y lirios, sus atributos conocidos. Iglesia San Francisco,

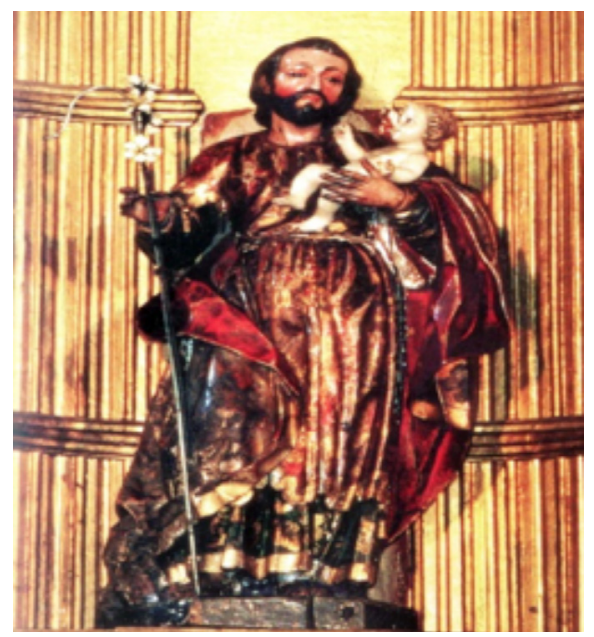

Fuente: Grupo Financiero El Ahorro Hondureño, 2000, p. 131.

el de San José, parecen ser de la misma mano de Gálvez, aunque en su testamento dado en Tegucigalpa, solo hace mención del Altar Mayor dorado, del púlpito y la hechura de las imágenes de las Ánimas y San José (Martínez, 1997).

Tanto la imaginería en la Catedral San Miguel Arcángel como en la Iglesia de Nuestra Señora de Los Dolores de Tegucigalpa son de vital importancia para comprender la teología de San José y su discurso iconológico ya que, en el testamento dejado por Don Pedro Mártir de Zelaya, el hombre más adinerado de Honduras en el siglo XVIII,
Declara que es su voluntad que a la Iglesia Parroquial de esta Villa se le den 4000 pesos, para concluir y colocar al señor San Joseph en su retablo, hacién- dole 6 blandones de 8 marcos cada uno, fundaran de ellos 1000 pesos para que con sus réditos se acelere la función del 19 de marzo de ese santo patriarca; pero en caso de que esta misma fundación se haga, el señalado día en la ermita de Nuestra Señora de los Dolores, se invertirá el redito de los 50 pesos de los 1000 señalados en la celebridad del patrocinio de este santo patriarca. (Oyuela, 1992, p. 131)

Para 1732, la Iglesia estaba ya adornada de retablos de talla dorada, los dos más antiguos son los ejecutados por el ensamblador y pintor Blas de Meza, que dedicó uno a San José, y el otro es una escultura en talla rodeada de pinturas alegóricas 
al santo. Ambos retablos son del estilo barroco salomónico, con sus columnas recubiertas de parras de uva (Martínez, 1997).

Entre las manifestaciones materiales del patrimonio cultural eclesiástico, los retablos son importantes para la comprensión y transmisión de la fe. Estos se pueden apreciar desde varios puntos de vista:

- Como comprensión del discurso iconológico o adoctrinador.

- Como configuración el espacio litúrgico dentro de un recinto religioso.

- Como una obra de arte, testimonio del estilo artístico de una época.

En resumen, es importante comprender los retablos y valorarlos desde lo simbólico y artístico, ya que al ser obras religiosas son veneradas solamente por una parte de la población y, además, sufren continuas modificaciones según el discurso de la Iglesia u otros factores. Su valor patrimonial se concentra en el conocimiento de su historia, significado y función.

\section{Devocionales. San José y el Niño}

Dado que se asume que José tuvo la gracia de estar al lado de Jesús durante su infancia, y se encargó de su educación y cuidado tan fervorosamente, la Iglesia católica lo hizo merecedor de la santidad. Tal reconocimiento hizo que en el siglo XVI San José se representara frecuentemente con el Niño Jesús. Indican Duchet-Suchaux \& Pastoureau (1996) que:

Fue Santa Teresa de Jesús quien definió el tipo de San José con su hijo portando un lirio y un hacha en las representaciones artísticas. El hacha y el lirio se relacionan con la virginidad del santo y el trabajo de carpintero. El lirio es el símbolo de la pureza y de acuerdo con la leyenda, está relacionado con la vara florida que brotó en el Templo cuando San José fue escogido como esposo de la Virgen María. (Luna, 2001, p. 17)

\section{La muerte de San José}

Gracias al texto "Los Dones de San José” de Isidorus Isolanus (Pavía, 1522), se dio a conocer el relato de la muerte de San José, Santo que fue ignorado durante la Edad Media, pero posteriormente se convirtió en motivo de inspiración para muchos artistas. Isolanus (Pavía, 1522), -citado por Mâle (1985)- expresa que Jesús cuenta directamente los últimos instantes de su padre nutricio:

Me siento a su cabecera y mi madre a sus pies. Entrelazo sus manos con las mías durante una larga hora. Los arcángeles Miguel y Gabriel se acercaron a él, y rindió el último suspiro con alegría. Yo le cerré los ojos con mis manos y los ángeles vinieron a vestirle con un traje blanco. (Luna, 2001, p. 19) 
Por su fallecimiento al lado del Salvador se designó como "el patrón de la buena muerte" de modo que se hicieron muchas representaciones de esta escena en pintura. Se cree que el tema nació a finales del s. XVI por la obra atribuida a Annibale Carracci. Esta imagen aparece a menudo en Italia, Francia y España.

La devoción a San José, en cierto modo, es como la de María, un signo de predestinación, pues se considera que es un "abogado de la buena muerte" que nunca deja de socorrer a sus fieles servidores en su última hora (Celajes, 1930, pág. 3).

Figura 5. "La sagrada familia" en la Iglesia Los Dolores de Tegucigalpa. Donde se aprecia a San José como esposo al cuidado de la Virgen y el Niño Jesús.

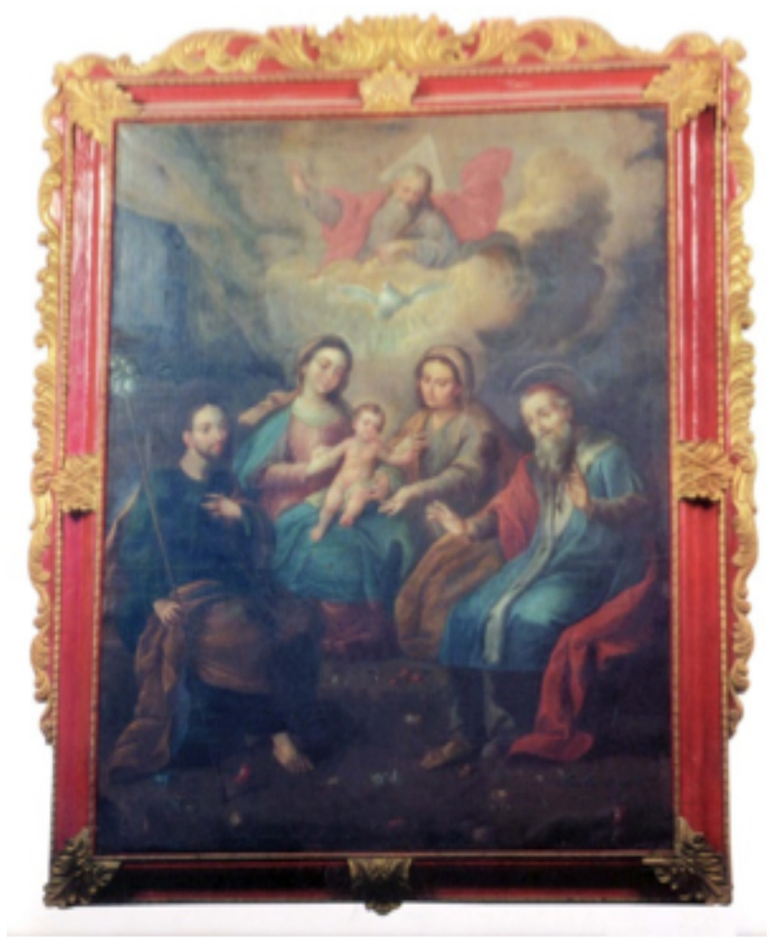

Fuente: Grupo Financiero El Ahorro Hondureño, 2000, p. 145.

\section{Devoción popular: Novenas y fiestas patronales}

El estudio de las fiestas y celebraciones tiene variadas implicaciones; algunas asociadas al ejercicio lúdico, creativo de la población, unas a expresiones de catarsis social y otras a sistemas simbólico-rituales (García \& Aragón, 2006). 
En esta misma línea García \& Aragón (2006):

explican que las fiestas y celebraciones son formas de catarsis social y están asociados a períodos de liminaridad cuando el hombre deja de hacer lo rutinario para festejar, celebrar, rememorar, conmemorar, recordar, añorar, renovar, agasajar, olvidar o modificar hechos, situaciones o mementos trascendentales de la vida que generan estados de angustia que son necesarios de afrontar, tratar o asumir de manera especial, dando licencia liminar a la rutina y desarrollando el talante creativo, festivo y fantástico. (p. 13)

La fiesta es en sí misma un rito social que permite remarcar un hecho o acontecimiento especial. Debe de ceñirse a patrones determinados, donde los participantes asumen diferentes roles en concordancia con esos patrones. Música, danza y comida son los acompañantes de este ritual. En las fiestas religiosas los dioses y santos son invocados para que haya buenas cosechas o para que no ocurran terremotos y que la naturaleza arroje frutos de bonanza. También se invoca a los dioses para pedir milagros de toda índole (Casanova, 2009).

Un caso concreto de cómo se celebran estas festividades, lo encontramos en el Municipio de Caridad, departamento de Valle, donde los moradores de esta población, desde hace muchas décadas, celebran el día del Patriarca San José y han designado para tal fin el 19 de marzo de cada año. Al ser esta la fiesta popular más grande del pueblo, se procura revestirla de la mayor solemnidad, siempre que las condiciones económicas lo permitan, concediendo mayor atención a la parte religiosa.

Los días 19, 20, 21 y 22 de marzo se celebran comuniones. De la misma forma el día 19 de marzo en horas de la tarde, la imagen del Patrón San José recorre las principales calles del lugar en una imponente procesión (Celajes, 1927, p. 452).

Esta misma festividad es celebrada en el Municipio de San José en el Departamento de Choluteca, donde el 19 de marzo los feligreses del municipio concurren a la iglesia a pagar sus promesas, celebran bodas, bautizos y una alborada en honor al cumpleaños de San José a las 4 de la mañana, sumado de una procesión acompañada de música y cohetes, donde también se arreglan y se cambian las vestimentas al santo (López, 2017).

Además de estas fiestas populares y a través de la tradición oral, surgen los imaginarios y creencias con respecto a la percepción existente sobre los santos, ejemplo de ello es lo expresado por María Félix Álvarez, rezadora del Municipio de San José, Choluteca:

Considero a San José como un hombre trabajador, quien laboraba en una montaña y se mantenía con mieles de colmenas de abeja. En cuanto al casorio de la 
Virgen María, se dice que ella era una niña muy linda, y que no podía ser que esta niña, se fuera a casar con cualquiera, sino que ojalá se casara con un hombre bien estudiado, y entonces dijeron que había que cortar una hoja o una rama de escobilla de chancho que le decimos [sic. malva sylvestris]; después hicieron una gran reunión para ver a quien le florecía, entonces convidaron a gente solo de corbata, varones y le fueron pasando uno a uno aquella rama seca y al caso que ninguno la hizo florecer, entonces dijeron falta uno, pero que es pobrecito, hay que ir a traerlo, que era San José.

Entonces cuando vino San José y le dieron la ramita, quien rápido la hizo florecer, es la esposa de él, dijeron. Pero no es que allí los casaron, si no que le dijeron que se la iban a entregar para que él la cuidara, se la entregaron y el la llevó a la montaña. A la niña, se la entregaron con la orden que si salía interesante [sic. embarazada] entonces iba ir preso, o lo iban a matar, era a cuidarla, y él se iba dice a trabajar y ella se quedaba solita. (Álvarez, 2017, s.p.)

En este sentido podemos observar como la religiosidad popular integra en el culto oficial la cosmovisión regional, la cual se expresa en los elementos propios del lugar que adopta o produce la manifestación, como considerar a San José una persona dedicada a la explotación de la miel y no al oficio de la carpintería.

Otro elemento propio de la religiosidad popular es la caracterización de los santos, quienes adoptan formas y costumbres de la vida de los pobladores. Es común, en reiteradas ocasiones, la existencia de un mismo santo con características distintas.

Figura 6. San José peregrino talla popular.

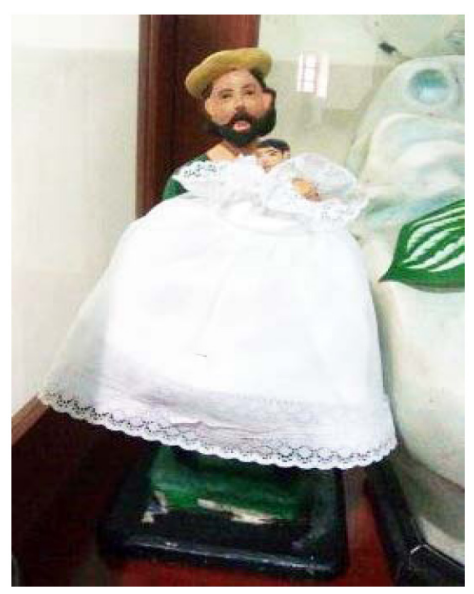

Figura 7. San José permanente y oficial.

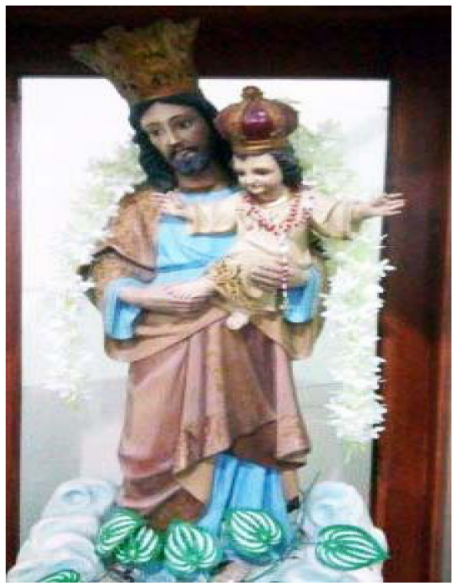

Fuente: Fotografías de Josué Omar Flores. Iglesia Católica del Municipio de San José, Choluteca, Honduras, 2017. 
Con el afán de crear devociones, las imágenes se van reproduciendo en cada pueblo. Siendo común encontrar en las iglesias dos imágenes representando a un mismo santo, una de menor tamaño, de madera, con la finalidad de poder moverla, llamándola santo de carga o peregrinación (Figura 6), y otra de mayor tamaño y menor movimiento (Figura 7). La imagen peregrina suele ser de mayor antigüedad y es la que tiene reconocimiento y adopción por parte de la comunidad, ya que acoge los patrones culturales del pueblo. En este caso miramos a un San José luciendo un sombrero y no una corona como es la representación oficial.

Así mismo, al ser una imagen peregrina, pasará de un espacio cerrado y de culto oficial a un espacio público y popular. Además, la presencia física de la imagen convierte el lugar que la alberga en un espacio estimado como milagroso, dotándolo de una singularidad en prestigio y beneficio económico (Sánchez del Olmo, 2015). Siguiendo esta interpretación, también a la imagen peregrina se le atribuyen propiedades curativas y milagrosas, y por ello cobra importancia la acción de peregrinar por todo su espacio o jurisdicción percibida como sagrada. De esta forma, la imagen circunscribe territorios sagrados, calles, caminos, ermitas, rocas y lugares de paso, que unen el centro con la periferia.

Un ejemplo de ello es la peregrinación de la imagen de San José, en el municipio de San José. Donde un mes antes de su celebración (17 de febrero-17 de marzo), la imagen es llevada a todas las aldeas cercanas con el objetivo de unificar a las familias y predicar el ejemplo de trabajo y humildad, así como para recolectar ofrendas destinadas a cubrir los gastos de su feria patronal (López, 2017). Creando de esta manera en las comunidades mecanismos de cohesión e interacción social, necesarios para ligar a los grupos dispersos en regiones centrales, posibilitando así una eventual acción de integración comunitaria.

\section{San José en la memoria colectiva hondureña}

San José es honrado cada 19 de marzo en Honduras, fecha en la que también el país celebra el día del Padre, celebración estipulada mediante decreto legislativo publicado en La Gaceta el 9 de febrero de 1960. En dicho decreto se considera que "el Padre es acreedor de la misma veneración, respeto y cariño que se le guarda a la Madre, pues en unión con ella, es un baluarte indiscutible en el santuario del hogar" (Heraldo, 2015, pág. 18).

Esta festividad de San José relacionada con la conmemoración del Día del Padre, se celebra en España y Portugal. En América, tanto Honduras como Bolivia son los países que mantienen esta herencia del imaginario colonial de San José, al institucionalizar la celebración desde el Estado. 
Además, cada 1 de mayo, las asociaciones de trabajadores católicos del país celebran a San José Obrero, promoviendo dentro de la conmemoración del Día Internacional del Trabajo, el espíritu evangélico entre empresarios y clase obrera en su lucha por el respeto a los diversos derechos laborales.

En el caso específico de Honduras, desde 1964 se erige en Choluteca la Parroquia de San José Obrero, que ha sido la encargada de enseñar a los obreros de la zona Sur del país las virtudes encarnadas por San José: persona trabajadora, humilde, ejemplar, padre de familia, amante del orden y guía en el camino de la redención.

Destacándose el valor simbólico del taller de Nazaret como modelo de familia trabajadora y de amor fraternal de los trabajadores; José representa el empresario perfecto y Jesús el trabajador ejemplar en los años que ayudó en el taller y al morir en la cruz por la salvación de los demás hombres. (Velasco, 2003, p. 101)

Además, la parroquia buscó solventar las necesidades de sus fieles como la carestía de fuentes de trabajo y de atención médica. Sobresale, en este sentido, el Presbítero Alejandro Flores quien abrió en la zona una pequeña clínica, una fábrica de guantes de trabajo, una fábrica de sillas y un taller de carpintería que traía el pan a la mesa de tantas familias de la zona. De igual forma, en este proceso, se encuentra la incomprensión de algunos obreros y sindicatos que tenían sospechas acerca de los verdaderos objetivos del Presbítero Flores, ya que lo miraban más como un empresario y no como un sacerdote (Guillet, 2005).

\section{Conclusiones}

El imaginario de San José en la cultura hondureña es constante debido al arraigo de esta devoción desde la época colonial, manifestándose en la pintura, escultura y arquitectura existentes en los templos coloniales y en las festividades. Esta devoción es vista desde la religiosidad popular como una acción integradora de la Iglesia con la comunidad.

La imagen de San José es adoptada por el Estado hondureño porque representa un ideal de paternidad para la sociedad, es un pilar fundamental de la unidad familiar y se considera al santo un esposo ejemplar, padre protector, responsable y trabajador. Y es que actualmente esta imagen no es adoptada de forma homogénea por la sociedad hondureña, debido a la diversidad de creencias religiosas y la inclusión de una conmemoración civil, de un Estado laico en el marco de una festividad religiosa.

Finalmente, encontramos a San José Obrero, afiliado en primera instancia al gremio de los carpinteros, para luego representar a la colectividad de trabajadores católicos, cuyas asociaciones le otorgarán el título de mediador en las 
relaciones entre obreros y patronos, al propugnar el respeto a los derechos laborales conquistados.

\section{Referencias bibliográficas}

Álvarez, M. F. (22 de Julio de 2017). Entrevista a la rezadora del Municipio de San José sobre las fiestas a San José. (J. O. Flores, Entrevistador) Cacerío Las Garzas, San José, Choluteca, Honduras.

Borrero, J. M. (1983). La pintura popular del Carmen, identidad y cultura en el siglo XVIII. Quito: CIDAP.

Burke, P. (2001). Visto y no visto. El uso de la imagen como documento histórico. Barcelona: Crítica.

Campos, F. J., \& OSA, F. d. (2014). Cofradías de San José en el mundo hispánico. Madrid: R.C.U. Escorial - M. Cristina Servicio de Publicaciones.

Casanova, J. G. (2009). Memorias X Encuentro para la Promoción y Difusión del Patrimonio Inmateril de Países Iberoamericanos. Fiestas y rituales. Perú: Dupligráficas Ltda.

Crónica de Nacaome. (24 de Julio de 1927). Celajes. Semanario Católico (139), p. 450 .

Ecos de Caridad. Fiesta del Patrón San José. (24 de Julio de 1927). Celajes. Semanario Católico (139), p. 452.

El Primero de Mayo entra en el calendario católico con la Fiesta de San José Obrero. Su Santidad habla a más de 150,000 trabajadores congregados en la Plaza de San Pedro. (Mayo - junio de 1955). Boletín Eclesiástico (40), p. 12.

El Santo de la Semana. San José. (14 de Marzo de 1948). El Buen Amigo. Semanario Católico (755), p. 9.

García, J. J., \& Aragón, K. T. (2006). Fiestas populares y tradicionales de Perú. Ecuador: Instituto Iberoamenrciano Natural y Cultural IPANC.

Gómez, J. H. (2007). Historiografía y hagiografía: vidas ejemplares y escritura de la historia en el Nuevo Reino de Granada. Revista Fronteras de la Historia (12), 53-78.

Grupo Financiero El Ahorro Hondureño para el fomento de la cultura y las artes. (2000). Por las Rutas de la Plata y el Añil, desarrollo del arte colonial religioso hondureño. Tegucigalpa. 
Gruzinski, S. (1994). La guerra de las imágenes. De Cristóbla Colon a Blade Runner. México: Fondo de Cultura Económica.

Guillet, P. (2005). Los Padres Javerianos y su obra. El clero hondureño, resultado de su trabajo de promoción. La transmisión de su carisma misionero. Sociedad de los Padres Misioneros Javerianos. Tegucigalpa: Talleres Gráficos de AZER Impresos.

Heraldo, D. E. (22 de Marzo de 2013). Día del Padre hondureño. Recuperado el 14 de octubre de 2017, de Día del Padre hondureno: http://www.elheraldo. hn/pais/823735-214/d\%C3\%ADa-del-padre-en-honduras.

Latuz, C. L. (Diciembre de 2016). En torno al concepto de religiosidad popular. Aistheis (60), 297-302.

Laurentino, M. H. (1982). Historia de la devoción y la teología de San José. THEOLOGICA, 1(14), 355-360.

López, M. E. (22 de Julio de 2017). Entrevista a la Delegada de la Palabra de Dios de San José sobre las fiestas patronales de San José. (J. O. Flores, Entrevistador) San José, Choluteca, Honduras.

Luna, M. (2001). La iconografia de San José en la colección de pintura del Museo de Arte Colonial de Nérida. Colombia: Universidad de Los Andes.

Mâle, E. (1996). El arte religioso del siglo XII al XVIII. México: Fondo de Cultura Económica.

Martínez, J. M. (2011). Arte y culto. El poder de la imagen religiosa. Chile: Colecciones del Museo Histórico Nacional.

Martínez, M. F. (1997). Cuatro centros de arte colonial provinciano hispano criollo en Honduras. Tegucigalpa: Editorial Universitaria.

Oyuela, L. d. (1992). Fe, riquesa y poder. Una antología crítica de docuemntos para la historia de Honduras. Tegucigalpa: Instituto Hondureño de Cultura Hispánica.

Oyuela, L. d. (1995). Honduras: Religiosidad popular. Raiz de la identidad. Choluteca: Centro de Publicaciones del Obispado de Choluteca.

Panofsky, E. (1987). El significado de las artes visuales. Madrid: Alianza .

Plazaola, J. (1996). Historia y sentido del arte cristiano. Madrid: Biblioteca de autores cristinos.

San José abogado de la buena muerte. (19 de Octubre de 1930). Celajes. Semanario Católico (554), p. 3. 
Sanchez del Olmo, S. (2015). Prodigiosa y peregrina...imagen mariana, tiempo sagrado e identidad colectiva en patzacuaro virreinal. En R. P. Luque, \& R. Castañeda García, Entre la Solemnidad y el regocijo: fiestas, devociones y religiosidad en Nueva España y el mundo hispànico. (pp. 161-181). Michoacàn: Colegio de Michoacàn: Centro de Investigaciones y Estudios Superiores en Antropologìa Social.

Undurraga, A. (s.f.). Evaluación de la religiosidad popular latinoamericana. Chile: Ediciones Paulinas.

Urquizú, F., \& Carrasco, N. R. (2016). Análisis iconográfico e iconológico de la catedral de San Miguel de Tegucigalpa. Estudios Digital (10).

Velasco, M. D. (2003). El Primero de mayo y su transformación en San José Artesano. AYER(54), 87-113.

Wide, A. J. (2018). ArtBible. Recuperado el 20 de Septiembre de 2017, de ArtBible: http://www.artbible.org/es/pintura-lucas-el-greco-san-jose-y-el-ninojesus-291/\#.Wk-aIN9sbIW 